\title{
TECHNICAL AND ECONOMICAL EVALUATIONS OF CALABRIAN PINE (PINUS BRUTIA TEN.) SEMI-ARID PLANTATIONS IN THE ŞANLIURFA-HARRAN PLAIN OF TURKEY
}

\author{
DAŞDEMIR, I..$^{1 *}$ - ÖZEL, H.-B. ${ }^{1}-$ KAYA, H. ${ }^{2}$ \\ ${ }^{1}$ Faculty of Forestry, Bartın University, Bartın, Turkey \\ (e-mails: isdasdemir@hotmail.com, halilbarisozel@yahoo.com) \\ ${ }^{2}$ Şanlıurfa Forest Enterprise Directorate, Şanlıurfa, Turkey \\ (e-mail: hakanky_01@hotmail.com) \\ *Corresponding author \\ e-mail: isdasdemir@hotmail.com \\ (Received $28^{\text {th }}$ Oct 2018; accepted $11^{\text {th }}$ Jan 2019)
}

\begin{abstract}
Determinations of success of semi-arid plantations are very important. This paper was handled to evaluate the success of Calabrian pine plantations established in the semi-arid Harran Plain of Turkey between 1996 and 1999 regarding technical and economic aspects. The data were obtained from both 12 sample plots at different aspects in 2015 and from the Sanliurfa Forest Enterprise Directorate's records. Also data of the yield tables of plantation areas and natural stands, and the product range table of Calabrian pine were used. Variance analysis was administered to control the growth performance of Calabrian pine plantations. The differences of diameter and height growths and the number of trees per hectare were determined. The criteria of net present value, internal rate of return and benefit cost ratio were used for economic evaluation. In conclusion, diameter and height growth and success rate were found higher in eastern, northern and western aspects, the mean survival percentage ranged from 18.60$57.13 \%$, and the high percentage of survival was found in the north aspect. Economic return of Calabrian pine plantations in semi-arid areas in terms of wood production was found to be lower than that of the natural stands and of the plantations in other areas. However, it was concluded that the plantations in semi-arid regions are crucial because of the benefits such as the biological diversity, the protection of natural balance, prevention of erosion and carbon sequestration, and incorporation of the wastelands to the production. It was suggested that the plantations in semi-arid area should be improved and maintained for sustainable environmental management.
\end{abstract}

Keywords: benefit cost ratio, internal rate of return, net present value, Pinus brutia, plantation growth performance, semi-arid region, sustainable environmental management

\section{Introduction}

As one of the countermeasures against global warming, afforestation in arid and semi-arid lands had been proposed and has been tested from 1999. In this areas, harsh environmental condition constrains plant growth and survival, and then biomass productivity is usually quite low (Suganuma et al., 2014). As plantations become increasingly important sources of wood and fiber in arid and semi-arid places, they have also become increasingly criticized for their hydrological impacts (Sadeghi et al., 2016). In arid and semi-arid regions, where rainfall is not sufficient to sustain a good seedling/tree growth, water harvesting for afforestation is applied (Prinz, 2001). On the other hand, in combating desertification and erosion, the most significant issue is to conduct successful plantation activities. With this aim, it needs well-designed plantation projects, a consideration of all details and accurate implementation of the projects 
(Niskanen, 1997; Ürgenç, 1998; Turna et al., 2007; Tunçtaner, 2007; Y1lmaz and Tonguç, 2010). Hence, the destruction of ecological balance brings the environmental problems that threaten the community life such as drought, erosion and flood, and such catastrophes led many people to say that forest sources are of significant functions in protecting community health care (Koçer et al., 2009; Oğuz et al., 2009). Other biological and mechanical measures should be taken into consideration alternatively in case of the lack of convenient conditions for plantations (Anonymous, 1999).

Afforestation area has grown rapidly over the last few decades in the semi-arid grasslands in the world in an effort to restore mountain vegetation. The reasons for this land-use change included an increasing demand for timber production (Chen et al., 2016). Hence, analyses of the rationale of forest plantations in many developing countries have often been focused on efficient wood production and financial return on invested capital (Niskanen, 1997). Afforestation is a key technique for the control of desertification and environmental deterioration in arid and semiarid regions. Therefore, it is important to quantify the influence of the succession that results from afforestation on biodiversity conservation and ecological environment (Liu et al., 2015). The most common afforestation efforts in the arid and semi-arid regions of Asia include planting plantations of Pinus eldarica, Cupressus arizonica, Robinia pseudoacacia, and Fraxinus rotundifolia (Harrington et al., 1989; Michelozzi et al., 2008; Motahari et al., 2013; Sadeghi et al., 2016). These species are frequently preferred because they are drought resistant and grow fast. For this aim, Pinus halepensis, Pinus brutia and Eucalyptus camaldulensis are also used with success in some countries.

Although the slumping hills or the ones prone to slump in erosion areas were temporarily stabilized through technical facilities with alluvial cones, avalanche corridors, sand and gravel deposits, the most effective and permanent measures are taken through plantations in the basin (Ürgenç, 1998). In order for a successful plantation in the areas with shallow and poor soil, little and irregular rainfall, high evaporation, insufficient organic materials and stony surface, it is important to provide funds for plantation activities without industrial concerns as well as recruiting knowledgeable and experienced technical staff. In arid and semi-arid planting lands, it is essential for a successful plantation to use local species and local races among these species which are compatible with the existent ecological conditions. Also, deep-rooted tree species should be used in these areas (Turna et al., 2006). Besides, it will also achieve success in terms of combating erosion by using advanced nursery techniques and certain methods reducing crop water stress (mulching, soil improver materials, seedling shelter etc.).

In Turkey, combating desertification and erosion began in 1955 and the activities continued in a more planned way after the foundation of General Directorate of Afforestation and Erosion Control. According to the data of the General Directorate of Forestry, 2.2 million ha of Turkey's forest area, which is 22.3 million ha, are subject to afforestation from ecological, technical and social aspects. The areas to be afforested in Turkey will reach to a total of 4.8 million ha when a million hectare public lands to be afforested and the areas, which are in 0.11-0.40 canopy and afforested with difficulty in terms of technical aspect since it has lost its natural regeneration conditions. And, this has added to 2.2 million ha (Ürgenç et al., 1993; Anonymous, 2001).

There is a report that $40 \%$ of Turkey's total area is suffering from drought and desertification is indispensable unless satisfactory measures are taken (Ürgenç, 1998). Furthermore, the most important issues as a result of global warming causing serious 
changes in climate systems are drought, desertification and erosion (Koçer et al., 2009). In this respect, it was stated that drought and desertification directly threatened more than 4 billion ha of area and a population of 1.2 billion people in 110 countries in "the United Nations Convention to Combat Desertification" which was accepted by the Intergovernmental Negotiating Committee in the United Nations Conference on Environment and Development on 17 June 1994 and was adopted by Turkey since 16 May 1998 (Anonymous, 2013). That is, desertification will result in erosion and, therefore, lead to yield loss, hunger and poverty in arable lands, pastures and woodlands (Turna et al., 2007). Only successful regeneration and plantation activities will make it possible to prevent this situation (Saatçioğlu, 1976; Atay, 1987; Ata, 1995).

Arid and semi-arid regions are fragile ecosystems. Sustainable management of arid and semi-arid areas requires good planning and careful implementation, as they have ecological, biological, technical and socio-economic constraints. Decisions related to the species and provenance selection, site preparation, spacing and other techniques and details should be made by paying attention to the specific conditions of these areas (Boydak and Çalışkan, 2015). In semi-arid area afforestation, it is the front plan to offer various benefits such as biodiversity service, protection of natural balance, prevention of erosion, etc., which often do not have a price in the market, rather than wood production. By estimating indirectly the economic values of such benefits and services, it is possible to add them in plantation incomes. In this case, it is obvious that the benefits will be very high. Although wood production is not for the purpose of production, there is also time to time wood production in these fields. Therefore, it is necessary to make economic evaluations in terms of wood production and compare with the natural stands in the same conditions.

This study was carried out in the plantation fields in the semi-arid and arid ŞanlıurfaHarran Plain in Turkey. These plantations established in the region between 1996 and 1999 years are arid/semi-arid plantations in the scope of combating erosion. Despite some studies related to technical and economical evaluations of plantations in general (Türker, 1986; Niskanen, 1997; Ahtikoski and Pulkkinen, 2003; Daşdemir and Şahin, 2006; Turna et al., 2007; Tuçtaner et al., 2012; Suganuma et al., 2014; Kulik et al., 2015; Wu et al., 2015), there are not many regarding particularly the economic evaluation of plantation activities in semi-arid areas. In this study, technical and economical evaluations were carried out in the plantation area in the Şanliurfa-Harran Plain by making measurements in the field in 2015 after 16-18 years of field installation. So, this research was conducted in order to investigate the success rate of plantations with Calabrian pine in semi-arid areas, determine the diameter and height growth as a result of half of the rotation age, and make economic evaluations based on wood production.

\section{Materials and methods}

\section{Study area}

The study was carried out in the Calabrian pine (Pinus brutia Ten.) plantation area established as Tofaş Memorial Forest in the period 1996-1999 in the Eyyübiye district of Şanliurfa (Harran Plain) of Turkey (Fig. 1). Calabrian pine is also known as Turkish pine, East Mediterranean pine and brutia pine. According to data of the Şanliurfa Meteorological Station (TSMS, 2015), the average annual temperature in the region was $18.4^{\circ} \mathrm{C}$. While the maximum temperature was $46.8^{\circ} \mathrm{C}$ in July and the minimum was - 
$11.4^{\circ} \mathrm{C}$ in February. The mean annual precipitation amount was $382 \mathrm{~mm}$ and the precipitation was $223 \mathrm{~mm}$ in the vegetation period. Since the places which receive a rainfall of $300 \mathrm{~mm}$ and below are considered to be arid and those which receive a rainfall between 300-600 mm are semi-arid, Şanluurfa is understood to be semi-arid. The general acreage of the plantation area is 77.33 ha and 64.40 ha of the total area were planted. Through this plantation was aimed to prevent moderate and heavy sheet erosion and gully erosion (Anonymous, 1997). The average height of the field is $423 \mathrm{~m}$ and soil structure is clay loam. In the plantations, $0+1$ aged, potted and Hatay originated Turkish pine seedlings were used. The planting distance was $3 \times 3 \mathrm{~m}$. The tilth was made with tractor + ripper plough in the plantation area and planting was made with labor force.



Figure 1. The location and a general view of the study area (up left: URL-1 2016, up right: URL-2 2016)

\section{Data and evaluation}

The materials for the study are as follows: the data obtained from the diameter, height measurements and the number of trees and their ages in the sample plots from different aspects in the plantation areas in 2015 was used for technical evaluations, the data from the Şanliurfa Forest Enterprise Directorate (plantation expenses, wood production costs, sale prices of wood, etc.). The yield table for Turkish pine plantation areas (Usta, 1991), the yield table for Turkish pine natural stands (Erkan, 1996) and barked volume ratios in the product range table of Turkish pine (Sun et al., 1977) was used for economical evaluations.

A total of 12 sample plots at 4 different aspects and heights, each measuring $20 \times 20$ $\mathrm{m}$ square sized with 3 repetitions, were taken in 2015 (Table 1). The number of trees, the heights and their $1.30 \mathrm{~m}$ diameters, and ages of five predominant (the tallest) trees were determined in each sample plot. 
Table 1. The features of sample plots

\begin{tabular}{c|c|c|c|c|c}
\hline \multirow{2}{*}{ Research area } & \multirow{2}{*}{ Species } & \multicolumn{4}{|c}{ Sample plots } \\
\cline { 3 - 6 } & & Aspect & Altitude (m) & Size $\left(\mathbf{m}^{2}\right)$ & Number (piece) \\
\hline \multirow{3}{*}{ Harran Plain- } & North & 400 & 400 & 3 \\
Tofaş Land & \multirow{4}{*}{ Calabrian pine } & South & 425 & 400 & 3 \\
& & East & 431 & 400 & 3 \\
& & West & 457 & 400 & 3 \\
\hline
\end{tabular}

The planting distance at the beginning $(3 \times 3 \mathrm{~m})$ was taken as a reference in order to find out the success rate in the plantation areas after 16-18 years. Thus, the success rate was measured by converting the current number of trees in the sample plots into hectare and proportioning them to the required seedling number $(1,111 \mathrm{pcs} / \mathrm{ha})$ in the plantations with the distance at the beginning. Moreover, the mean diameter and height was determined at the sample plot level by calculating the arithmetic mean of diameters and heights. The mean success rate, diameter and height values were obtained from the sample plots according to different aspects. In this study one way variance analysis (ANOVA) were administered and the differences between the mean rates were determined by Duncan Range Test. For this purpose, SPSS 22.0 package program was used.

The economic evaluations of the plantation areas were made in relation to income and expense accounts of wood production (ȘFED, 2015). Firstly, the site index of the plantation area was determined. For this, the heights and ages of five predominant trees were measured. By taking the top height and age means of five predominant trees as a reference, the top mean height and age of sample plots at each aspect were measured. The site class of the sample plots, rotation age $(\mathrm{u})$, and the highest mean increment in that site class were determined based on the top mean height, age and $3 \times 3 \mathrm{~m}$ potential growth area by using the yield table for Turkish pine plantation areas (Usta, 1991). The intermediate yields $\left(D_{1}, D_{2}, \ldots\right)$ during the rotation age benefiting from the yield table and final yield amounts $\left(\mathrm{A}_{\mathrm{u}}\right)$ were determined. As the plantation areas were bare at the beginning, the yield from the area was taken as null before the application. Likewise, the site index and yield table made by Erkan (1996) for Turkish pine natural stands, the rotation age for the related site index, intermediate and final wood production volumes were determined. The intermediate and final yield sizes were classified into product ranges using barked volume ratios in the product range table for Turkish pine by Sun et al. (1977).

The production costs (stumpage price + loading + transportation + stacking-sorting + storage) and auction sale prices according to product range were taken from the Production Cost Sheet and General Sale Sheet in the 2015 balance sheet of the Şanliurfa Forest Enterprise Directorate (ŞFED, 2015). The net selling prices were calculated by extracting production costs from selling prices of the products. The net incomes were found by multiplying the net selling prices by the intermediate and final yields in terms of product ranges for both plantation areas and natural stands. Also, Calabrian pine plantation costs (establishment, maintenance, sapling cost and other expenses) were taken from the records of the Directorate for the machine + labor force production technology with 2015 prices (US\$/ha) and were added into the economic analyses. 
Taking into consideration of the determined incomes and expenses, economical analyses were made by the use of the following criteria as Net Present Value (NPV) (Eq. 1), Internal Rate of Return (IRR) (Eq. 2) and Benefit Cost Ratio (BCR) (Eq. 3) (Geray, 1986; Türker, 1986; Erkan, 2002; Daşdemir and Şahin, 2006; Tunçtaner et al., 2012; Daşdemir, 2012, 2015; Bijarpas et al., 2015):

$$
\begin{gathered}
N P V=\sum_{t=0}^{n} \frac{B_{t}}{(1+i)^{t}}-\sum_{t=0}^{n} \frac{C_{t}}{(1+i)^{t}} \\
\operatorname{IRR}\left(i_{r}\right) \rightarrow N P V=0=\sum_{t=0}^{n} \frac{B_{t}-C_{t}}{\left(1+i_{r}\right)^{t}} \\
B C R=\frac{\sum_{t=0}^{n} \frac{B_{t}}{(1+i)^{t}}}{\sum_{t=0}^{n} \frac{C_{t}}{(1+i)^{t}}}
\end{gathered}
$$

In the formulas, $B_{t}$ shows revenues in the $\mathrm{t}$ year, $C_{t}$ shows costs in the $\mathrm{t}$ year, $n$ is rotation age, $i$ is interest rate and $i_{r}$ is internal rate of return (IRR). In the research, $\mathrm{P}=3 \%$ forestry little interest rate was used in NPV and BCR calculations. IRR is calculated by iteration method using different interest rates in the Excel software. The current prices of 2017 have been used in the calculations.

In this study, the economic analyses were made only in terms of wood production without considering the advantages such as biodiversity service of semi-arid regional plantations, the protection of natural balance, prevention of erosion, etc., and they were compared with the economic returns of natural brutia pine stands under the same conditions.

\section{Results}

\section{Results related to the technical analysis of plantations}

According to the results of the variance analysis, the survival percentage, height and breast height diameter $\left(\mathrm{d}_{1.30}\right)$ of the young saplings were found to vary according to the aspects (Table 2).

When examined the results of the variance analysis related to the variables such as diameter, height and survival percent in Table 2, it was found that there is a significant difference among the aspects of three variables at a confidence level of $\mathrm{P}<0.01$. Therefore, a Duncan test was conducted in order to determine homogenous groups in terms of the examined variables (diameter, height, survival percentage). The Duncan test results related to the variables of diameter, height and survival percent, which are important in terms of growth and adaptation in the evaluation of plantation activities, were shown in Table 3.

From the mean values examined in Table 3, it is understood that breast height diameter growth ranges from 13.49 to $15.20 \mathrm{~cm}$. According to the Duncan test, three different groups were emerged in terms of breast diameter growth at a confidence level of $\mathrm{P}<0.01$. When taking into consideration age difference in the Calabrian pine 
plantations at different aspects, it was ascertained that on the northern aspects growth was better than other aspects in terms of mean diameter growth, and it decreased especially among those towards the south aspects despite the age difference. The height was found to range 3.66-6.25 $\mathrm{m}$ according to the aspects. In the result of the Duncan test at a confidence level of $\mathrm{P}<0.01$, three different homogenous groups were determined among the aspects in terms of the variable of height (Table 3). One of the significant variables in determining the adaptability of plantations is the mean survival percentage. It was found out that the mean survival percentage ranges from 18.60 to $57.13 \%$. According to Duncan test results; the survival percentage at a confidence level of $\mathrm{P}<0.01$ forms three different homogenous groups in terms of the aspects (Table 3). These results show that the high percentage of survival is seen in the north aspect while the lowest one is in the south aspect. Despite the age difference, the mean survival percentage is seen to be higher in north and eastern (shady) aspects rather than southern and western (sunny) aspects.

Table 2. The results of one way variance analysis related to Calabrian pine plantations

\begin{tabular}{c|c|c|c|c|c|c}
\hline \multicolumn{2}{c}{ Variation source } & $\begin{array}{c}\text { Sum of } \\
\text { squares }\end{array}$ & $\begin{array}{c}\text { Degree of } \\
\text { freedom }\end{array}$ & Mean square & F value & $\begin{array}{c}\text { Significance } \\
\text { level }\end{array}$ \\
\hline \multirow{3}{*}{ Diameter } & Between groups & 5.693 & 3 & 1.898 & & \\
& Within groups & 0.596 & 8 & 0.074 & 25.484 & 0.000 \\
& Total & 6.289 & 11 & & & \\
\hline \multirow{3}{*}{ Height } & Between groups & 13.531 & 3 & 4.510 & & \multirow{2}{*}{0.000} \\
& Within groups & 0.034 & 8 & 0.004 & 1061.276 & \\
\hline \multirow{3}{*}{ Survival } & Total & 13.565 & 11 & & & \\
percentage & Between groups & 2615.469 & 3 & 871.823 & & \\
& Within groups & 163.000 & 8 & 20.375 & 42.789 & \\
& Total & 2778.469 & 11 & & & \\
\hline
\end{tabular}

Table 3. Duncan range test results related to Calabrian pine plantations

\begin{tabular}{c|c|c|c|c}
\hline Research area & Aspect & Diameter $(\mathbf{c m})$ & Height $(\mathbf{m})$ & Survival percentage (\%) \\
\hline \multirow{5}{*}{ Harran Plain } & South & $13.49^{\mathrm{a}}$ & $3.66^{\mathrm{a}}$ & $18.60^{\mathrm{a}}$ \\
& West & $14.49^{\mathrm{b}}$ & $5.90^{\mathrm{b}}$ & $23.97^{\mathrm{ab}}$ \\
& East & $15.13^{\mathrm{c}}$ & $6.14^{\mathrm{c}}$ & $32.33^{\mathrm{b}}$ \\
& North & $15.20^{\mathrm{c}}$ & $6.25^{\mathrm{c}}$ & $57.13^{\mathrm{c}}$ \\
& Mean & 14.58 & 5.49 & 33.01 \\
\hline
\end{tabular}

a: fist group, b: second group, c: third group

\section{Results related to the economic analysis of plantations}

Site index, rotation age, thinning age and intensity, volume results

Based on the top age and height values from the sample plots, the top height and age averages were measured at the aspects. From the yield table produced for Turkish pine plantation areas by Usta (1991), it was found out that all the sample plots were in the third (bad) site class based on the top height, age and $3 \times 3 \mathrm{~m}\left(9 \mathrm{~m}^{2} ; 1,111\right.$ trees in per 
hectare) potential growth area (Table 4). According to this table, the top height in partially shady (northern, eastern and western) aspects is higher than that in the south. This shows that water-humidity is the minimum factor limiting the growth in semi-arid areas.

Table 4. The top height, age and site index at the aspects of Calabrian pine plantation area

\begin{tabular}{c|c|c|c|c}
\hline \multicolumn{2}{c|}{ Sample plot } & \multirow{2}{*}{ Top height $(\mathbf{m})$} & $\begin{array}{c}\text { Age } \\
\text { (year) }\end{array}$ & $\begin{array}{c}\text { Site index } \\
\text { (Third class = III = bad site) }\end{array}$ \\
\cline { 1 - 2 } Aspect & Number (piece) & & 18 & III \\
North & 3 & 6.26 & 16 & III \\
South & 3 & 3.80 & 18 & III \\
East & 3 & 6.53 & 17 & III \\
West & 3 & 6.06 & 17 & III \\
\hline \multicolumn{2}{c|}{ Mean } & 5.66 &
\end{tabular}

By using the yield table prepared by Usta (1991), the 33rd age with the highest average volume increment was identified as rotation age for the $3 \times 3 \mathrm{~m}\left(9 \mathrm{~m}^{2}\right)$ potential growth area in the third site index. Likewise, the only thinning age was taken as the $25^{\text {th }}$ age determined by Usta (1991), and it was assumed that the thinning treatments was applied at $35 \%$ intensity. Also, $35 \%\left(21.35 \mathrm{~m}^{3)}\right.$ of $61 \mathrm{~m}^{3}$ volume given by Usta (1991) for the $25^{\text {th }}$ age was taken as the intermediate yield $\left(\mathrm{D}_{25}\right)$. Assuming that a thinning treatment of $35 \%$ intensity applied at the $25^{\text {th }}$ age increased the gap-distance by $35 \%$, the volume of the final yield $\left(\mathrm{A}_{33}\right)$ at the $35^{\text {th }}$ age was taken as $95.5 \mathrm{~m}^{3}$ corresponding to $12 \mathrm{~m}^{2}$ potential growth area.

For natural Turkish pine stands the yield table and site index prepared by Erkan (1996) were used. The site class which is close to the top height $(5.66 \mathrm{~m})$ and age (17 years old) values in the sample areas in the triple site classification table of Erkan (1996) belong to third class. The yield table of 13.3 site index which is close to 12.5 as the average of this class was used. The rotation age in this table was 45 years, and it was supposed that first thinning was at the age of $25\left(D_{25}=15.68 \mathrm{~m}^{3}\right)$, second thinning was at the age of $35\left(\mathrm{D}_{35}=20.67 \mathrm{~m}^{3}\right)$ and the final yield was at the age of $45\left(\mathrm{~A}_{45}=138.23+\right.$ $\left.19.25=157.48 \mathrm{~m}^{3}\right)$.

\section{Income and cost findings}

The intermediate and final yield volumes determined for both natural Calabrian pine stands and plantation areas were distinguished into product ranges based on the medium diameter values that corresponded to these volumes in the related yield table and using the barked volume ratios in the product range table prepared by Sun et al. (1977). The net selling prices were calculated by extracting production costs from the auction sale prices in terms of production range of the Şanliurfa Forest Enterprise Directorate (Table 5). The net incomes were calculated by multiplying the number of production range by net selling prices.

On the other hand, the cost of 1 ha plantation area (establishment, maintenance, sapling cost and other expenses) was determined as 2,467.17 US $\$ /$ ha at 2015 prices based on unit prices of the General Directorate of Forestry for the option of machine + labor production technology. 
Table 5. Production costs and sale prices according to product types of Calabrian pine (as of 2015)

\begin{tabular}{c|c|c|c|c}
\hline Tree species & Product types & $\begin{array}{c}\text { Production cost } \\
\text { (US\$) }\end{array}$ & $\begin{array}{c}\text { Sale price } \\
\text { (US\$) }\end{array}$ & $\begin{array}{c}\text { Net sale price } \\
\text { (US\$) }\end{array}$ \\
\hline \multirow{5}{*}{ Calabrian pine } & Log $\left(\mathrm{m}^{3}\right)$ & 21.87 & 78.57 & 56.69 \\
& Mine pole $\left(\mathrm{m}^{3}\right)$ & 21.87 & 65.06 & 43.19 \\
& Industrial wood $\left(\mathrm{m}^{3}\right)$ & 15.31 & 61.89 & 46.58 \\
& Fuel wood $\left(\mathrm{m}^{3}\right)$ & 17.19 & 28.10 & 10.91 \\
\hline
\end{tabular}

\section{Findings of net present value, internal rate of return and benefit cost ratio}

The rotation age, thinning ages and third site class were determined in the way described above for brutia pine plantations and natural stands. The economic analyses were made using NPV, IRR and BCR criteria based on net selling prices, plantation costs, and the intermediate and final yield volumes determined by the help of the related yield tables and product range table. The calculations were made based on the 2015 prices (Table 6).

In order to eliminate the effect of rotation age, the annual mean NPVs were calculated by dividing NPVs (US\$/ha) calculated for plantation areas and natural stands to rotation age. According to this, the annual NPVs are calculated as $29.52 \mathrm{US} \$ / \mathrm{ha} / \mathrm{year}$ for the option of plantation area + bad site +33 year rotation age and $-15.64 \mathrm{US} \$ /$ ha/year for the option of natural stand + bad site +45 year rotation age. Therefore, it was found that natural brutia pine stands in the same site index had a higher NPV than that of brutia pine plantations in semi-arid regions in terms of wood production according to NPVs calculated for both the whole rotation age and annually.

In the above calculations, NPV, IRR and BCR values were calculated according to the assumption that success of plantation areas was $100 \%$ (optimal). However, since the success was determined to be $33.01 \%$ in the plantation areas because of several reasons (Table 3), the incomes from the fields were multiplied by these success rates and thus actual economic results were achieved and the results were shared in Table 7. Because the yield tables for the natural stands reflected the real situation of the areas, the optimal and actual situations of them were the same.

According to Tables 6 and 7, NPVs of both natural stands and plantation areas with $3 \%$ interest rate in the third site index areas were found negative. However, the NPV of plantation areas is smaller. Considering the actual success of plantation areas, the NPV is even smaller. Similarly, IRR and BCR values of plantation areas are smaller in natural stands. This most probably stems from the fact that the plantation area is in semi-arid regions and the success rate is low.

\section{Discussion and conclusion}

In this study, technical and economical evaluations were carried out by making measurements in the plantation area in the Şanliurfa-Harran Plain of Turkey as a result of half of the rotation age in 2015 after 16-18 years from establishment of the area. In this research, it was determined that the top mean height value was $6.25 \mathrm{~m}$ for Calabrian pine in the plantation area of the Harran Plain, the top mean breast diameter value was $15.20 \mathrm{~cm}$ and the top mean survival percentage was $57.13 \%$ in northern and eastern 


$$
\text { - } 1766 \text { - }
$$

(shady) aspects (Table 3). According to the variance analysis, significant differences were estimated at a confidence level of $\mathrm{P}<0.01$ in spite of the age differences in the aspects (Table 2). The mean values of such variables were determined to decrease from the shady aspects towards sunny (southern and western) aspects by Duncan test (Table 3).

Table 6. Net present value, internal rate of return and benefit cost ratio calculations for the Calabrian pine plantation area and the natural stand

\begin{tabular}{|c|c|c|c|c|c|c|c|c|}
\hline \multirow[t]{2}{*}{ Site } & \multirow{2}{*}{$\begin{array}{l}\text { Site } \\
\text { index }\end{array}$} & \multirow{2}{*}{$\begin{array}{c}\text { Rotation } \\
\text { period }\end{array}$} & \multirow{2}{*}{$\begin{array}{c}\text { Return } \\
\text { years }\end{array}$} & \multirow[t]{2}{*}{ Product types } & \multirow{2}{*}{$\begin{array}{c}\begin{array}{c}\text { Amount of } \\
\text { product }\end{array} \\
\left(\mathrm{m}^{3} / \mathrm{ha}\right) \\
\end{array}$} & \multirow{2}{*}{$\begin{array}{c}\begin{array}{c}\text { Net sale } \\
\text { price }\end{array} \\
\left(\mathbf{U S} \$ / \mathbf{m}^{3}\right)\end{array}$} & \multicolumn{2}{|c|}{$\begin{array}{l}\text { Reduced net incomes } \\
\text { (US } \$ / \text { ha) }\end{array}$} \\
\hline & & & & & & & $P=0.03$ & $P=0.01$ \\
\hline \multirow{12}{*}{ 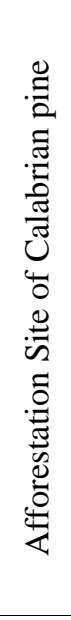 } & \multirow{12}{*}{$\begin{array}{c}\text { III } \\
(\mathrm{Bad})\end{array}$} & \multirow{12}{*}{33} & \multirow{3}{*}{$\mathrm{D}_{25}$} & Fuel wood & 6.6 & 10.91 & 34.40 & 56.17 \\
\hline & & & & Industrial wood & 6.73 & 46.58 & 149.73 & 244.46 \\
\hline & & & & Mine pole & 8.03 & 43.19 & 165.63 & 270.41 \\
\hline & & & \multirow{4}{*}{$\mathrm{A}_{33}$} & Fuel wood & 36.67 & 10.91 & 150.89 & 288.19 \\
\hline & & & & Industrial wood & 26.84 & 46.58 & 471.39 & 900.33 \\
\hline & & & & Mine pole & 31.99 & 43.19 & 520.87 & 994.84 \\
\hline & & & & $\log$ & 0 & 56.69 & 0.00 & 0.00 \\
\hline & & & \multicolumn{4}{|c|}{ Total of incomes (US\$/ha) } & $1,492.91$ & $2,754.40$ \\
\hline & & & \multicolumn{4}{|c|}{ Total of outcomes (US\$/ha) } & $2,467.17$ & $2,467.17$ \\
\hline & & & \multicolumn{4}{|c|}{ NPV (US\$/ha) } & -974.14 & 287.24 \\
\hline & & & \multicolumn{4}{|c|}{$\operatorname{IRR}(\%)$} & \multicolumn{2}{|c|}{1.46} \\
\hline & & & \multicolumn{4}{|c|}{$\mathrm{BCR}$} & \multicolumn{2}{|c|}{0.61} \\
\hline & & & & & & & $\mathrm{P}=0.03$ & $\mathrm{P}=0.02$ \\
\hline \multirow{15}{*}{ 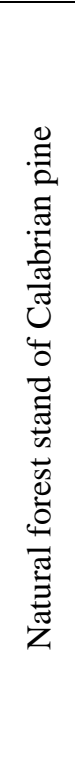 } & \multirow{15}{*}{$\begin{array}{l}\text { III } \\
(\mathrm{Bad})\end{array}$} & \multirow{15}{*}{45} & \multirow{3}{*}{$\mathrm{D}_{25}$} & Fuel wood & 4.85 & 10.91 & 25.28 & 32.26 \\
\hline & & & & Industrial wood & 4.94 & 46.58 & 109.91 & 140.27 \\
\hline & & & & Mine pole & 5.9 & 43.19 & 121.69 & 155.31 \\
\hline & & & \multirow{3}{*}{$\mathrm{D}_{35}$} & Fuel wood & 6.95 & 10.91 & 26.96 & 37.93 \\
\hline & & & & Industrial wood & 6.26 & 46.58 & 103.63 & 145.81 \\
\hline & & & & Mine pole & 7.46 & 43.19 & 114.49 & 161.09 \\
\hline & & & \multirow{4}{*}{$\mathrm{A}_{45}$} & Fuel wood & 67.24 & 10.91 & 194.06 & 301.02 \\
\hline & & & & Industrial wood & 41.1 & 46.58 & 506.28 & 785.34 \\
\hline & & & & Mine pole & 49.13 & 43.19 & 561.07 & 870.33 \\
\hline & & & & $\log$ & 0 & 56.69 & 0.00 & 0.00 \\
\hline & & & \multicolumn{4}{|c|}{ Total of incomes (US\$/ha) } & $1,763.37$ & $2,629.36$ \\
\hline & & & \multicolumn{4}{|c|}{ Total of outcomes (US\$/ha) } & $2,467.19$ & $2,467.19$ \\
\hline & & & \multicolumn{4}{|c|}{ NPV (US\$/ha) } & -703.79 & 162.07 \\
\hline & & & \multicolumn{4}{|c|}{$\operatorname{IRR}(\%)$} & & \\
\hline & & & & $\mathrm{BC}$ & & & & \\
\hline
\end{tabular}

NPV: net present value, IRR: internal rate of return, BCR: benefit cost ratio

The mean height, mean diameter and mean survival percentage of the research area are generally at a low rate. But, when considered that the general ecological structure of the research area falls under the domain of a semi-arid climate zone, the stated diameter and height growth and survival percentage in this plantation area can be said to be at a 
satisfactory level and value in terms of prevention of erosion in the region and soil conservation. In a research study that was conducted in the black pine plantation areas of the Konya-Karapınar region which had similar ecological conditions to those of this research (Özel, 2010); its growth and survival percentage were found to be low. The function of black pine in order to protect especially agricultural areas against endemic wind erosion and the consequential soil erosion was of crucial importance. Similarly Eucalyptus camaldulensis was considered as the most suitable tree species for arid land afforestation of Western Australia, by comparing biomass growth and survival ratio of planted trees (Suganuma et al., 2014). Along with this, the variable of survival percentage is a significant one in order to determine adaptability of the species used in the plantation activities (Ürgenç, 1998; Tunçtaner, 2007). That this variable reaches up to $57.13 \%$ at the northern aspects in a poor plantation circumstances under semi-arid climate conditions like the study area will be useful in terms of the implementation and sustainability of protective forest functions such as erosion control, carbon sequestration and recreation. A study made in the semiarid desert steppe of China showed that afforestation greatly affected the community and habitat characteristics, and promoted the formation of the crust on the soil surface with the succession of vegetation (Liu et al., 2015). In this regard, it is important to establish new forest areas in different plantation conditions and to manage them functionally against catastrophic disasters such as erosion, flood and avalanche as a result of the destructions of Turkey's forest resources, irregular urbanization and industrialization.

Table 7. Net present value, internal rate of return and benefit cost ratio values for Calabrian pine according to optimal and actual situation

\begin{tabular}{|c|c|c|c|c|c|c|c|c|}
\hline \multirow{2}{*}{ Stand type } & \multirow{2}{*}{$\begin{array}{c}\text { Site } \\
\text { index }\end{array}$} & \multirow{2}{*}{$\begin{array}{c}\text { Rotation } \\
\text { period } \\
\text { (year) }\end{array}$} & \multicolumn{3}{|c|}{$\begin{array}{c}\text { According to optimal } \\
\text { situation }\end{array}$} & \multicolumn{3}{|c|}{ According to actual situation } \\
\hline & & & $\begin{array}{c}\text { NPV } \\
\text { (US\$/ha) }\end{array}$ & $\begin{array}{l}\text { IRR } \\
(\%)\end{array}$ & BCR & $\begin{array}{c}\text { NPV } \\
\text { (US\$/ha) }\end{array}$ & $\begin{array}{l}\text { IRR } \\
(\%)\end{array}$ & BCR \\
\hline Afforestation & $\mathrm{Bad}$ & 33 & -974 & 1.46 & 0.61 & $-1,974$ & 1.25 & 0.20 \\
\hline Natural forest stand & $\mathrm{Bad}$ & 45 & -704 & 2.19 & 0.71 & -704 & 2.19 & 0.71 \\
\hline
\end{tabular}

NPV: net present value, IRR: internal rate of return, BCR: benefit cost ratio

In Turkey, a total of 57.17 million ha are exposed to moderate and severe erosion. The amount of soil loss due to erosion eliminates the primary sources for agricultural production, cultivated for nutrition in semi-arid and arid regions especially of the countries whose forests have been destroyed. While a total of $585.6 \mathrm{ton} / \mathrm{km}^{2}$ topsoil is lost because of floods in Turkey, this rate is $31.3 \mathrm{ton} / \mathrm{km}^{2}$ in Europe (Çepel, 1992; Dağdaş, 2007). The places which experience erosion are mostly arid and semi-arid areas in Turkey and the world (Fidan, 2006). In the plantation of such areas where there is poor and shallow soil and of erosion risk, some applications should be used such as the selection of appropriate species and origins, the use of potted seedlings which are of quality root-shoot balance and mycorrhizal vaccines as well as some cultural rehabilitation activities (Ürgenç, 1998; Boydak and Çalıkoğlu, 2006). Especially the use of quality seedlings has a special importance in terms of the plantation success. The quality seedling should be of a balanced root-shoot rate and sufficient capillary root density (Turna et al., 2007). What is more, by protecting the existent vegetation where there is a risk of drought, desertification and severe erosion, it will make the plantations 
successful to make use of natural species and local races which have adaptability. In this regard, the successful samples of erosion control, dune and arid area plantations that need special techniques can be found in Turkey (Boydak and Çalıkoğlu, 2006; Ayan et al., 2007).

Arid and semi-arid afforestations have many environmental and protector impacts. Afforestation decreases percent cover and aboveground biomass, and increase plant diversity of herbaceous community. Afforestation also decreases soil bulk density and $\mathrm{pH}$, and increased soil water content (Chen et al., 2016). Moreover, afforestation increases soil organic carbon and nitrogen storage in semi-arid grass lands, which has important implications for $\mathrm{C}$ sequestration. In the arid and semi-arid regions, water supply is the main factor limiting sustainable development of planted forests (Wang et al., 2011; Chen et al., 2016).

On the other hand, a thorough plantation in semi-arid areas reduces seedling survival percentage significantly. It is thought to be an important factor on the low survival percentage of brutia pine seedlings in the study area. In this regard, it is necessary first to protect the area and provide soil stability by placing endemic and existent annual and perennial plant species in order to reduce earth movement. Since greening which is also called as temporary and pre-stabilization activity enables to improve physical soil properties and increase organic ingredients in soil, it boosts significantly the achievement of the main plantation activity or the adaptation success of permanent stabilization activity. In this issue, similar outcomes are achieved in the research studies aimed at controlling erosion in the Eastern Anatolia Region and it is recommended that the natural vegetation should be protected and prohibited for pasturage before plantations (Daşdemir et al., 1996; Daşdemir, 2006). Besides, it is observed that the research areas are anthropogenic steppe areas where the black pine and oak forests are cleared in order to grow crops and consequently they are faced with a moderate and severe risk as a result of denudation. Hence, it is more convenient that the plantation is maintained with the drought-tolerant origins of a local species, black pine, in such plantation areas. Also, leaved species should be partly utilized where local climatic factors are suitable. Therefore, it will enable plantation activities to be carried out swiftly and genetic diversity to be protected.

Economic analyses were made by taking third class $\left(\mathrm{III}^{\text {th }}=\right.$ bad $)$ site, 33 and 45 year rotation age and machine + labor force production technology into consideration in terms of only wood production for the natural Calabrian pine stands and the Calabrian pine plantations in the Şanlıurfa-Harran Plain (Table 6). The NPV, IRR and BCR values of each option were calculated according to optimal and actual situation. According to the both situations, the NPV, IRR and BCR values of natural stands are greater than those of plantation areas (Table 7). According to this, NPV $=-974 \mathrm{US} \$ / \mathrm{ha}$, IRR $=$ $1.46 \%$ and $\mathrm{BCR}=0.61$ for the option of plantation area + bad site +33 years rotation age $; \mathrm{NPV}=-704 \mathrm{US} \$ / \mathrm{ha}, \mathrm{IRR}=2.19 \%$ and $\mathrm{BCR}=0.71$ for the option of natural stand + bad site +45 years rotation age.

In this issue, in a research study carried out on the Turkish pine plantations of the Bartın region (Daşdemir and Şahin, 2005), the lowest NPV and IRR values were found to be as follows: NPV $=217.45 \mathrm{US} \$ / \mathrm{ha}$ and IRR $=4.28 \%$ for the option of bad site + 33 years rotation age + labor force. On the other hand, in another study carried out in the Antalya region by Erkan et al. (2002), the lowest NPV $=-23.845$ US $\$ /$ ha and IRR $=$ $4.48 \%$ in 40 years rotation age for brutia pine without the exception of production techniques. Economical profitability with $10 \%$ discount rate was found as a value 
chancing between 311 and 3,863 US\$/ha according to different afforestation options in afforestation with fast-growing eucalyptus species in Northeast Thailand (Niskanen, 1997). Hence, NPV and IRR values of the Calabrian pine plantations in the SanliurfaHarran Plain are lower than those of both natural and planted Calabrian pine stands in other regions in the same site index. It mainly stems from that the plantation areas are in semi-arid regions, the growth-increment is limited, the success rate is low and plantation expenses are high.

Even if Calabrian pine plantations in semi-arid areas are of low income in terms of wood production, they play an important role because they bear significant benefits and services such as the services of biological diversity, the production of natural balance, prevention of erosion, carbon sequestration, recreation, employment in addition to wood production. Among the studied environmental impacts of afforestation, carbon sequestration and transpiration are most important in economic terms (Niskanen, 1997). As a result of taking into consideration these benefits and services, which are priceless but is estimated indirectly, it will be seen that semi-arid area plantations are of high benefit. In this regard, in a study of erosion control by Daşdemir et al. (1996) in the Erzincan region, the price of such benefits and services was estimated as $4.50 \mathrm{US} \$ / \mathrm{ha}$ with 1994 prices and BCR $=1.37$. Similarly, in a research study in the Bartin region (Daşdemir and Seğmen, 2009), such benefits and services were estimated to be $33.58 \mathrm{US} \$ /$ ha at 2004 prices. Provided that these benefits and services are taken into consideration, it is obvious that the plantations in semi-arid areas will be of high income. Therefore, the potential semi-arid plantations should be accelerated as well as industrial plantations for wood production in good site areas. In addition, economic efficiency and cost minimization principles should be obeyed as much as required in semi-arid plantations and the highest success should be targeted with a minimum cost.

\section{REFERENCES}

[1] Ahtikoski, A., Pulkkinen, P. (2003): Cost-benefit analysis of using orchard or stand seed in scots pine sowing, the case of Northern in Finland. - New Forests 26: 247-262.

[2] Anonymous (1997): Tofaş Memorial Forest Afforestation and Application Project. Şanlıurfa Forest Enterprises Directorate, Department of Afforestation Chief Engineering, Şanlıurfa (in Turkish).

[3] Anonymous (1999): Considerations in Erosion Control Applications. - Ministry of Forestry, General Directorate of Afforestation and Erosion Control, Ankara (in Turkish).

[4] Anonymous (2001): Turkey Afforestation Action Plan (2001-2020). - Ministry of Forestry, General Directorate of Afforestation and Erosion Control, Ankara (in Turkish).

[5] Anonymous (2013): National Strategy Document for Combating. - Republic of Turkey, Ministry of Forestry and Water Affairs, General Directorate of Combating Desertification and Erosion, Ankara, Turkey.

[6] Ata, C. (1995): Silviculture Techniques. - Zonguldak Karaelmas University Publication No: 4, Forestry Faculty Publication No: 3, Bartın (in Turkish).

[7] Atay, İ. (1987): Natural Regeneration Methods I-II. - İstanbul University Publication No: 3461, Graduate School of Natural and Applied Sciences Publication No: 1, İstanbul (in Turkish).

[8] Ayan, S., Sivacioğlu, A., Öner, N., Demircioğlu, N. (2007): Soil amendments in the arid and semi-arid areas for preserving the plant vigour. - Workshop of Assessment of Forestation and Erosion Control Applications in Semi-arid Regions in Turkey, 07-10 November 2006, I. Volume, Ürgüp, Turkey, pp. 183-90 (in Turkish). 
[9] Bijarpas, M., M., Shahraji, T., R., Limaei, S., M. (2015): Socioeconomic evaluation of agroforestry systems (Case study: Northern Iran). - Journal of Forest Science 61(811): 478-484.

[10] Boydak, M., Çalıkoğlu, M. (2007): Planting spacings in the semi-arid zone afforestations. - Workshop of Assessment of Forestation and Erosion Control Applications in Semi-arid Regions in Turkey, 07-10 November 2006, I. Volume, Ürgüp, Turkey, pp. 166-168 (in Turkish).

[11] Boydak, M., Çalışkan, S. (2015): Afforestation in Arid and Semi-Arid Regions. Republic of Turkey, Ministry of Forestry and Water Affairs, General Directorate of Combating Desertification and Erosion, Ankara, Turkey.

[12] Çepel, N. (1992): Nature-Environment-Ecology and Ecological Problems of Humanity (1st Ed.). - Altın Kitaplar Publisher, İstanbul (in Turkish).

[13] Chen, L., He, Z., Zhu, X., Du, J., Yang, J., Li, J. (2016): Impacts of afforestation on plant diversity, soil properties, and soil organic carbon storage in a semi-arid grassland of northwestern China. - Catena 147(2016): 300-307.

[14] Dağdaş, S. (2007): Assessment of afforestation techniques in semi-arid regions (priority tree species and ecosystem rehabilitation). - Workshop of Assessment of Forestation and Erosion Control Applications in Semi-arid Regions in Turkey, 07-10 November 2006, I. Volume, Ürgüp, Turkey, pp. 388-405 (in Turkish).

[15] Daşdemir, İ. (2006): Some evaluations on methodology and economical feasibility of afforestation and erosion control applications in the region of north-eastern Anatolia. Workshop of Assessment of Forestation and Erosion Control Applications in Semi-arid Regions in Turkey, 07-10 November 2006, I. Volume, Ürgüp, Turkey, pp. 321-332 (in Turkish).

[16] Daşdemir, İ. (2012): Planning and Project Evaluation for Forest Engineering (2nd Ed.). Bartın University Publication No: 6, Forest Faculty Publication No: 4, Bartın, Turkey (in Turkish).

[17] Daşdemir, İ. (2015): Forestry Enterprise Economics (3rd Ed.). - Bartın University Publication No: 10, Forest Faculty Publication No: 6, Bartın, Turkey (in Turkish).

[18] Daşdemir, İ., Şahin, A. (2005): Economical evaluation of plantations alternatives in the Bartın Region. - ZKU, Review of Bartın Faculty of Forestry, Year 2002-2003-2004, 4(4): 38-53 (in Turkish).

[19] Daşdemir, İ., Şahin, A. (2006): Economic analysis of industrial afforestation investments: Bartın Example. - I. Congress on Socio-Economic Problems in Forestry, 26-28 May 2006, Proceeding Book, Ilgaz, Turkey, pp. 189-195 (in Turkish).

[20] Daşdemir, İ., Seğmen, C. (2009): The place of forestry sector in the Bartın province and its importance. - Journal of Forest Faculty of Bartın University, Special Issue, Volume I, 5, Bartın, pp. 43-53 (in Turkish).

[21] Daşdemir, İ., Tetik, M., Güven, M., Doğukan, H. (1996): Determination of plant species which can be used for prevention of erosion in the Eastern Anatolia region and erosion prevention studies to be done with them. - Eastern Anatolia Forestry Research Directorate, Technical Report No: 1, Erzurum (in Turkish).

[22] Erkan, N. (1996): Stand simulation for Pinus brutia Ten. - Southeastern Anatolia Forestry Research Directorate, Technical Bulletin No: 1, Elazığ, Turkey (in Turkish).

[23] Erkan, N. (2002): Growth performance of Calabrian pine (Pinus brutia Ten.) in Natural Forest and Plantations in Turkey. - Proceedings of IUFRO Meeting Management of Fast Growing Plantations, İzmit, Turkey, pp. 67-74 (in Turkish).

[24] Erkan, N., Uzun, E., Baş, M., N. (2002): Economical analyses for Pinus brutia Ten. plantations. - Southwest Anatolia Forestry Research Institute, Technical Bulletin No: 17, Antalya, Turkey (in Turkish).

[25] Fidan, C. (2007): Place and importance of herbaceous plants in erosion control studies in semi-arid regions. - Workshop of Assessment of Forestation and Erosion Control 
Applications in Semi-arid Regions in Turkey, 07-10 November 2006, I. Volume, Ürgüp, Turkey, pp. 373-381 (in Turkish).

[26] Geray, A., U. (1986): Planning lecture notes. - İstanbul (in Turkish).

[27] Harrington, J., T., Mexal, J., G., Fisher, J., T. (1989): Seed set and germination of eldarica pine influenced by cone hierarchy. - In: Landis, T. D. (ed.) Proceedings, Intermountain Forest Nursery Association; 1989 August 14-18; General Technical Report RM-184, Bismarck, ND.

[28] Koçer, F., Kurt, L., İmali, A., Karahan, F. (2009): Ecological impacts of global warming. - Proceedings of 1th National Drought and Desertification Symposium, 16-18 June 2009, Konya, pp. 205-213 (in Turkish).

[29] Kulik, K., N., Barabanov, A., T., Manaenkov, A., S. (2015): Forecasting the development of protective afforestation in Russia until 2020. - Studies on Russian Economic Development 26(4): 351-358.

[30] Liu, B., Zhao, W., Liu, Z., Yang, Y., Luo, W., Zhou, H., Zhang, Y. (2015): Changes in species diversity, aboveground biomass, and vegetation cover along an afforestation successional gradient in a semiarid desert steppe of China. - Ecological Engineering 81: 301-311.

[31] Motahari, M., Attarod, P., Pypker, T., G., Etemad, V., Shirvany, A. (2013): Rainfall interception in a Pinus eldarica plantation in a semi-arid climate zone: An application of the Gash Model. - J. Agr. Sci. Tech. 15: 981-994.

[32] Michelozzi, M., Tognetti, R., Maggino, F., Radicati, M. (2008): Seasonal variations in monoterpene profiles and ecophysiological traits in Mediterranean Pine species of group "halepensis". - iForest 1: 65-74.

[33] Niskanen, A. (1997): Economic profitability of afforestation in Thailand and the Philippines. - Project Appraisal 12(3): 193-203. DOI: 10.1080/02688867.1997.9727058, Beech Tree Publishing, England.

[34] Oğuz, C., Kan, A., Kan, M. (2009): Evaluation of the drought and desertification within poverty phenomenon according to rural development. - Proceedings of 1th National Drought and Desertification Symposium, 16-18 June 2009, Konya, pp. 302-314 (in Turkish).

[35] Özel, H., B. (2010): Evaluation of growth performance of black pine (Pinus nigra Arnold. subsp. pallasiana (Lamb.) Holmboe) in arid zone afforestations in the Karapinar region. - Proceedings of 1th National Drought and Desertification Symposium, 16-18 June 2009, Konya, pp. 129-135 (in Turkish).

[36] Prinz, D. (2001): Water harvesting for afforestation in dry areas. - Proceedings, 10th International Conference on Rainwater Catchment Systems, Mannheim, 10-14 Sept. 2001, pp. 195-198.

[37] Saatçioğlu, F. (1976): Silviculture I, Biological Basis and Principles of Silviculture (2nd Ed.). - İstanbul University Publication No: 2187, Forestry Faculty Publication No: 222, İstanbul (in Turkish).

[38] Sadeghi, S., M., M., Attarod, P., Stan, J., T., V., Pypker, T., G. (2016): The importance of considering rainfall partitioning in afforestation initiatives in semiarid climates: A comparison of common planted tree species in Tehran, Iran. - Science of the Total Environment 568: 845-855.

[39] Suganuma, H., Omori, T., Sato, N., Hamano, H., Takahashi, N., Utsugi, H., Kojima, T., Yamada, K. (2014): Selection of Appropriate planting methods and tree species for arid land afforestation in Western Australia. - Journal of Arid Land Studies 23-4: 193-198.

[40] Sun, O., Eren, M., E., Orpak, M. (1977): Determination of Wood Variety Rates per Single Tree and Unit Area of Our Basic Tree Species. - TÜBITTAK/TOAG Project No: 288, Ankara, Turkey (in Turkish).

[41] ŞFED (2015): 2015 Balance Sheet Production Cost Table and General Sales Table. Şanlıurfa Forest Enterprise Directorate, Şanlıurfa (in Turkish). 
[42] TSMS (2015): Turkish State Meteorological Service, Şanlıurfa Meteorological Station data. - https://mgm.gov.tr/eng/forecast-cities.aspx?m=Sanliurfa/29.10.2015 (in Turkish).

[43] Tunçtaner, K. (2007): Forest genetic and tree improvement. - Turkey Forester Association, Training Document, No: 4, Ankara (in Turkish).

[44] Tunçtaner, K., Daşdemir, İ., Ertekin, M., Özel, H., B. (2012): Technical and economical evaluations of maritime pine plantations in the Western Black Sea region of Turkey. Journal of the Faculty of Forestry, Istanbul University 62(1): 31-45, İstanbul.

[45] Türker, A. (1986): Multicriteria decision making in afforestation. - Ph.D. Thesis, İstanbul University Natural and Applied Science Institution, İstanbul, Turkey (in Turkish).

[46] Turna, İ., Altun, L., Üçler, A., Ö., Tazegün, T. (2007): General evaluation of afforestation activities in arid and semi-arid regions. - Workshop of Assessment of Forestation and Erosion Control Applications in Semi-arid Regions in Turkey, 07-10 November 2006, I. Volume, Ürgüp, Turkey, pp. 33-42 (in Turkish).

[47] Usta, H., Z. (1991): A Study on the yield of Pinus brutia Ten. plantations. - Turkish Forest Research Institute Publications, Technical Bulletin No: 219, Ankara (in Turkish).

[48] URL-1 (2016): Turkey's place in the world https://www.valeuraenergy.com/operations/turkey/overview.html.26.11.2016.

[49] URL-2 (2016): Position of Şanlıurfa in the map of Turkey. https://tr.m.wikipedia.org/wiki/Dosya:Latrans-Turkey_location.26.11.2016.

[50] Ürgenç, S. (1998): Afforestation Techniques. - İstanbul University Publication No: 3994, Forestry Faculty Publication No: 441, Emek Publisher, İstanbul (in Turkish).

[51] Ürgenç, S., Boydak, M., Dirik, H. (1993): The location, objectives of afforestations in Turkey forestry and planning principles of afforestation investments. - Proceedings of 1 th Forestry Forum, Vol. 1, No: 13(006), Ankara, pp. 646-653 (in Turkish).

[52] Yılmaz, M., Tonguç, F. (2010): A native tree for restoration of semi-arid areas in Turkey: downy oak (Quercus pubescens Wild.) - Proceedings of 1th National Drought and Desertification Symposium, 16-18 June 2009, Konya, pp. 163-165 (in Turkish).

[53] Wang, Y., Shao, M., A., Zhu, Y., Liu, Z. (2011): Impacts of land use and plant characteristics on dried soil layers in different climatic regions on the loess plateau of China. - Agric. For. Meteorol 151(4): 437-448.

[54] Wu, Y., Q., Weng, Y., H., Hennigar, C., Lantz, V. (2015): Benefit-cost analysis of a white spruce clonal seed orchard in New Brunswick, Canada. - New Forests 46: 141-156. 